\title{
Absolute copy number differences of $Y$ chromosomal genes between crossbred (Bos taurus $\times$ Bos indicus) and Indicine bulls
}

\author{
Ayan Mukherjee ${ }^{1 *}$, Gulshan Dass ${ }^{1}$, Jagan Mohanarao $\mathrm{G}^{1,2}$, Moloya Gohain', Biswajit Brahma ${ }^{1}$,
} Tirtha Kumar Datta ${ }^{1}$ and Sachinandan De ${ }^{1}$

\begin{abstract}
Background: The $Y$ chromosome in mammal is paternally inherited and harbors genes related to male fertility and spermatogenesis. The unique intra-chromosomal recombination pattern of $Y$ chromosome and morphological difference of this chromosome between Bos taurus and Bos indicus make it an ideal model for studying structural variation, especially in crossbred (Bos taurus $\times$ Bos indicus) bulls. Copy Number Variation (CNV) is a type of genomic structural variation that gives information complementary to SNP data. The purpose of this study was to find out copy number differences of four Y chromosomal spermatogenesis-related candidate genes in genomic DNA of crossbred and purebred Indicine bulls.

Result: Four $Y$ chromosomal candidate genes of spermatogenesis namely, sex determining gene on Y chromosome (SRY), DEAD box polypeptide 3-Y chromosome (DDX3Y), Ubiquitin specific peptidase 9, Y-linked (USP9Y), testis-specific protein on Y chromosome (TSPY) were evaluated. Absolute copy numbers of Y chromosomal genes were determined by standard curve-based quantitative real time PCR. Copy numbers of SRY and TSPY genes per unit amount of genomic DNA are higher in crossbred than Indicine bulls. However, no difference was observed in DDX3Y and USP9Y gene copy numbers between two groups.

Conclusion: The present study demonstrates that the structural organization of $Y$ chromosomes differs between crossbred and Indicine bulls which are reproductively healthy as observed from analysis of semen attributes. The absolute copy numbers of SRY and TSPY genes in unit mass of genomic DNA of crossbred bulls are significantly higher than Indicine bulls. No alteration in absolute copies of DDX3Y and USP9Y gene was found between the genome of crossbred and Indicine bulls. This study suggests that the DDX3Y and USP9Y are likely to be single copy genes in the genome of crossbred and Indicine bulls and variation in Y chromosome length between crossbred and Indicine bulls may be due to the copy number variation of SRY gene and TSPY array.
\end{abstract}

Keywords: Absolute copy, SRY, DDX3Y, USP9Y, TSPY, Crossbred

\section{Background}

The Y chromosome plays an essential role in male sex development, spermatogenesis and male fertility [1]. The eutherian Y chromosome has unique characteristic feature that most part of this chromosome escapes meiotic recombination process with $\mathrm{X}$ chromosome except two regions at the tips of the $\mathrm{X}$ and $\mathrm{Y}$ chromosomes [2,3]. In absence of inter-chromosomal recombination the repeated gene sequences within a chromatid or between sister chromatids act as substrates for recombination. This unique

\footnotetext{
* Correspondence: ayanabtc@gmail.com

${ }^{1}$ Animal Genomics Lab, Animal Biotechnology Centre, National Dairy

Research Institute, Karnal, India

Full list of author information is available at the end of the article
}

recombination pattern of $\mathrm{Y}$ chromosome with its $\mathrm{X}$ counterpart makes it prone to structural variation [4]. Changes in DNA content and structure are a significant source of genetic and phenotypic variation among individuals [5-8]. These types of structural variations ranging from 1 kilobase $(\mathrm{kb})$ to 5 megabase $(\mathrm{Mb})$ comprised mainly of copy number variation ( $\mathrm{CNV}$ in the form of large-scale insertions and deletions), as well as inversions and translocations.

Studies on human Y chromosome has indicated the presence of 78 protein coding genes that encode 27 (18 single copy genes and 9 gene families) distinct proteins [3]. SRY gene encodes a protein product containing HMG box domain. The domain binds to DNA in the

\section{Biomed Central}


minor groove at a 6-base consensus target sequence and subsequently activates the cascade of testis determining pathway [9]. DDX3Y and USP9Y genes are construed as 'fine-tuner' of normal spermatogenesis process [10-12]. The protein product of the TSPY gene probably interacts with type B cyclins and activates cyclin B-CDK complexes. The activated complex, in turn, impacts on biological machineries in spermatogonial cell renewal and in prophase I spermatocyte differentiation [13].

Crossbreeding between taurine (Bos taurus) and indigenous cattle (Bos indicus) is a popular practice in Indian dairy industry. Semen of three exotic breeds namely, European Holstein Friesian, Brown Swiss and Jersey are extensively used for this purpose. The karyotypes of two bovine subspecies Bos taurus and Bos indicus have a high similarity except for the morphology of the Y chromosome [14]. Y chromosome in Bos taurus is submetacentric and acrocentric in Bos indicus. This morphological difference between Bos taurus and Bos indicus $\mathrm{Y}$ chromosome is the consequence of pericentric inversion [15]. In crossbred animal this difference in $\mathrm{Y}$ chromosome morphology may lead to small deletions or altered position between the synapse region of the $\mathrm{X}$ and $\mathrm{Y}$ chromosomes, or change in genes present on sex chromosomes. So far no study has been conducted on $\mathrm{Y}$ chromosomal gene copy number determination and their comparison between crossbred and Indicine bulls. Therefore, present study was designed to investigate absolute copy number differences of major Y chromosomal genes SRY, DDX3Y, USP9Y and TSPY between Karan Fries (a crossbred) and Sahiwal (purebred Bos indicus). We included reproductively healthy bulls in this study to avoid animals having poor semen quality which could be sequelae to the detrimental changes in $\mathrm{Y}$ chromosomal gene copies.

\section{Methods}

\section{Animals and semen collection}

All the experimental procedures involving animals were approved by the Institutional Animal Ethics Committee (IAEC), National Dairy Research Institute, Karnal, India. The seminal attributes of the bulls under study were assessed and those consistently producing good quality semen were included in the study. Semen samples were collected from 10 Karan Fries (F1 generation crossbred of Holstein-Friesian sire and Tharparkar or Sahiwal dam) and 10 Sahiwal (purebred Bos indicus) bulls by artificial vagina (IMV, L'Aigele cedex, France) in the early morning. The volume of the semen was measured in a graduated conical tube, mass motility was evaluated by light microscopy and sperm concentration was estimated using Haemocytometer [16] immediately after collection. The semen samples were processed for assessing the sperm quality parameters without any further delay.

\section{Assessment of seminal quality parameters}

We assessed progressive motility, plasmalemma and acrosomal integrity of the spermatozoa to evaluate the bulls as these are the most common semen evaluation tests in cattle. The percentage of sperm showing progressive forward motility was determined by mixing $100 \mu \mathrm{L}$ of undiluted semen into pre-warmed tubes containing $900 \mu \mathrm{L}$ of Tris buffer ( $\mathrm{pH} 7.2$ ). A thin drop of diluted semen was placed on a pre-warmed glass slide $\left(37^{\circ} \mathrm{C}\right)$ and evaluated under microscope. The mean of the three estimations was used as the final motility score [17]. 6-carboxyfluorescein diacetate (CFDA) and propidium iodide (PI) staining was done to assess the sperm viability as described by Selvaraju et al. [18]. Briefly, semen sample was incubated with phosphate buffered saline (PBS) based CFDA/PI staining solution at $37^{\circ} \mathrm{C}$ for $15 \mathrm{~min}$. After incubation, $0.2 \%$ glutaraldehyde was added and stained sample were examined under magnifications of $400 \times$ using an Olympus BX51 microscope (Olympus America, Center Valley, PA, USA) equipped with CFDA filter set (excitation, 510$560 \mathrm{~nm}$; emission, $505 \mathrm{~nm}$ ). The sperm showing complete green fluorescence were considered plasmalemma intact (live), and the cells showing partial or complete red nuclei were classified as dead. The hypo osmotic swelling test was performed for assessment of sperm membrane integrity based on curled and swollen tails. The assay was performed mixing neat semen with $150 \mathrm{mOsm} / \mathrm{L}$ hypoosmotic solution (13.51 g fructose $+7.35 \mathrm{~g}$ trisodium citrate per liter of distilled water) and incubating at $38.5^{\circ} \mathrm{C}$ for $1 \mathrm{~h}$ [19]. After incubation, semen sample was examined under the high power magnification $(400 \times)$ of a bright field microscope. Acrosomal integrity of the sperm was assessed by staining air-dried smears with fluorescein isothiocyanate-conjugated pisum sativum agglutinin (FITC-PSA) staining [20]. Air-dried smear was flooded with the FITC-PSA and kept in darkness for 30 min. Slides were washed in distilled water and mounted with glycerol with a cover slip. The fluorescence pattern of 200 sperm in randomly selected fields was determined under Olympus BX51 microscope (Olympus America, Center Valley, PA, USA) with 1,000× magnification. The proportions of intact, reacting, and reacted acrosome were expressed as percentages of the respective patterns in the total number of sperm counted [21].

\section{Collection of blood and isolation of genomic DNA}

About $10 \mathrm{~mL}$ of blood sample was collected from each animal in sterile Vacutainer ${ }^{\circledR}$ (Beckton-Dickinson, Franklin Lakes, NJ, USA) containing sodium heparin as an anticoagulant. The collected samples were stored at $4^{\circ} \mathrm{C}$ and transported to the laboratory at the earliest. The genomic DNA was isolated from white blood cells using standard phenol-chloroform procedure [22]. The DNA samples were dissolved in TE buffer ( $\mathrm{pH} 8.0$ ), their concentrations 
were determined by optical density at $260 \mathrm{~nm}$ using NanoDrop 1000 Spectrophotometer (Thermo Fisher Scientific, Wilmington, DE, USA) and stored at $-20^{\circ} \mathrm{C}$ for further use.

\section{Determination of absolute copy number Preparation of SRY, DDX3Y, USP9Y and TSPY plasmid constructs}

Fragments of SRY (736 bp), DDX3Y (2,010 bp), USP9Y (1,646 bp) were amplified from cDNA of peripheral blood lymphocyte. TSPY (1,141 bp) gene was amplified from testicular tissue of bull as the expression of the gene is testisspecific. PCR was carried out on an Eppendorf Mastercycler (Eppendorf, Hamburg, Germany) in a $25 \mu \mathrm{L}$ reaction mixture containing $2.5 \mu \mathrm{L}$ of $10 \times$ Paq5000 reaction buffer (provides a final $\mathrm{Mg}^{+2}$ concentration of $\left.2 \mathrm{mmol} / \mathrm{L}\right), 200 \mu \mathrm{mol} / \mathrm{L}$ of dNTPs (Fermentas, Lithuania), $500 \mathrm{nmol} / \mathrm{L}$ of each primer and 0.5 units of Stratagene Paq5000 ${ }^{\mathrm{max}}$ DNA polymerase (Agilent Technologies, West Cedar Creek, TX, USA). Details of the PCR primers used for amplifying these genes are listed in Table 1.

Amplified fragments were cloned separately into pcr $^{\circledR} 2.1$ vector $(3.9 \mathrm{~kb})$ using the TOPO TA Cloning ${ }^{\circledR}$ system (Invitrogen Corporation, Carlsbad, CA, USA) and plasmids were isolated with the Qiagen Plasmid isolation kit (Qiagen $\mathrm{GmBH}$, Hilden, Germany).

\section{Construction of standard curve}

Concentrations of plasmids containing SRY, DDX3Y, $U S P 9 Y$ and TSPY inserts were adjusted at $100 \mathrm{ng} / \mu \mathrm{L}$ using NanoDrop 1000 Spectrophotometer (Thermo Fisher Scientific, Wilmington, DE, USA). The concentration of the plasmid was converted to corresponding copy concentration using the following equation [23]

$$
\text { DNA copy }=\frac{6.023 \times 10^{23}(\text { copies } / \mathrm{mol}) \times \text { DNA amount }(g)}{(\text { Plasmid }+ \text { Insert }) \text { length }(\mathrm{bp}) \times 660(\mathrm{gm} / \mathrm{mol} / \mathrm{bp})}
$$

A tenfold dilution series of each of the plasmid constructs were used to construct the corresponding standard curves of two genes. Standard dilutions of each of the gene were assayed in triplicate. The $\mathrm{Cp}$ values were plotted against the logarithm of their initial template copy concentrations. Each standard curve was generated by a linear regression of the plotted points. From the slope of each curve, PCR amplification efficiency (E) was calculated according to the following equation [24]:

$$
E=10^{-1 / \text { slope }}-1
$$

\section{Quantitative PCR}

To determine the absolute copy number of SRY, USP9Y, $D D X 3 Y$ and TSPY genes in genomic DNA samples of bulls under study the gene-specific primers were designed. The sequences of the primer sets used for real-time PCR analysis are shown in Table 2. The primers were amplified on a LightCycler ${ }^{\circledR} 480$ instrument with software version 1.5 (Roche Diagnostics, Mannheim, Germany). Concentrations of all the DNA samples of test bulls were adjusted to $10 \mathrm{ng} / \mu \mathrm{L}$. The 'crossing point' or $\mathrm{Cp}$ values were determined by 'second-derivative max method' in the software. All realtime PCR runs were performed in triplicate and each reaction mixture was prepared using the KAPA SYBR ${ }^{\circledR}$ FAST qPCR kit (Kapa Biosystems, Woburn, MA, USA) in a total volume of $10 \mu \mathrm{L}$. Reaction for TSPY gene comprised of $2.4 \mu \mathrm{L}$ PCR-grade water (Sigma-Aldrich, St. Louis, MO, USA), $300 \mathrm{nmol} / \mathrm{L}$ each primer, $1 \times$ KAPA SYBR $^{\circledR}$ FAST qPCR Master Mix and $2 \mu \mathrm{L}$ of template DNA and that for SRY,DDX3Y and USP9Y comprised of $2 \mu \mathrm{L}$ PCR-grade water (Sigma-Aldrich, St. Louis, MO, USA), $500 \mathrm{nmol} / \mathrm{L}$ each primer, 1X KAPA SYBR ${ }^{\circledR}$ FAST qPCR Master Mix and $2 \mu \mathrm{L}$ of template DNA.

The following cycling conditions were employed for all the genes: pre-incubation at $95^{\circ} \mathrm{C}$ for $3 \mathrm{~min}$, followed by 40 cycles of $10 \mathrm{~s}$ at $95^{\circ} \mathrm{C}, 20 \mathrm{~s}$ at $60^{\circ} \mathrm{C}$, and $1 \mathrm{~s}$ at $72^{\circ} \mathrm{C}$. The fluorescence signal was measured at the end of each extension step at $72^{\circ} \mathrm{C}$. After the amplification, a melting peak analysis with a temperature gradient of $0.1^{\circ} \mathrm{C} / \mathrm{s}$ from 65 to $95^{\circ} \mathrm{C}$ was performed. Finally, the samples were cooled down to $40^{\circ} \mathrm{C}$ for $10 \mathrm{~s}$.

\begin{tabular}{|c|c|c|c|}
\hline Primer & Sequence, $5^{\prime}$ to $3^{\prime}$ & Melting temperature, $T_{m}$ & Product length, bp \\
\hline \multirow[t]{2}{*}{$S R Y$} & F: CGCAGTGCAGTCGTATGCTTCTGC & $61^{\circ} \mathrm{C}$ & 736 \\
\hline & R: GAGCGCCTITGTTAGCGAGAGTAAGG & $61^{\circ} \mathrm{C}$ & \\
\hline \multirow[t]{2}{*}{$D D X 3 Y$} & F: TTCGCGCCTTTCTTCAGGCATGAGTCA & $61^{\circ} \mathrm{C}$ & 2010 \\
\hline & R: CAGATTCAGTTGCCCCACCAGTCAAC & $61^{\circ} \mathrm{C}$ & \\
\hline \multirow[t]{2}{*}{ USP9Y } & F: TGTGGGACTCAAAAATGCTGGTGCTAC & $60^{\circ} \mathrm{C}$ & 1646 \\
\hline & R: ACTCCAGAAGGTATTCAGAGAAACGATTTGA & $59^{\circ} \mathrm{C}$ & \\
\hline \multirow[t]{2}{*}{$T S P Y$} & F: ATGTCGCGTCCCTTCGCCTCTGC & $62^{\circ} \mathrm{C}$ & 1141 \\
\hline & R: TCAGTTGTCTCTCATGGACGAACCTTCCT & $62^{\circ} \mathrm{C}$ & \\
\hline
\end{tabular}

Table 1 Primers used to amplify the gene fragments 
Table 2 Primers used for quantitative real time PCR

\begin{tabular}{|c|c|c|c|}
\hline Primer & Sequence, $5^{\prime}$ to $3^{\prime}$ & Melting temperature, $T_{m}$ & Product length, bp \\
\hline \multirow[t]{2}{*}{$S R Y$} & F: CTAGAGAATCCCAAAATGAAAAACTC & $53^{\circ} \mathrm{C}$ & 150 \\
\hline & R: ATATTTATAGCCCGGGTATTTGTCTC & $55^{\circ} \mathrm{C}$ & \\
\hline \multirow[t]{2}{*}{$D D X 3 Y$} & F: GTTAGATTTCTGCAAATACTTGGTGTT & $59^{\circ} \mathrm{C}$ & 101 \\
\hline & R: GCATAGTGTCTTGTTCAATTATACGAC & $60^{\circ} \mathrm{C}$ & \\
\hline \multirow[t]{2}{*}{ USP9Y } & F: GTACACAGTGGTCAAGCAAGTGGTG & $59^{\circ} \mathrm{C}$ & 178 \\
\hline & R: CTTCTCCCATGTACTCTCCACCAAA & $58^{\circ} \mathrm{C}$ & \\
\hline \multirow[t]{2}{*}{$T S P Y$} & F: AGTTGTGAGCCCAGTTGTCA & $52^{\circ} \mathrm{C}$ & 148 \\
\hline & R: CACCTCCTCCACGATGTCTT & $54^{\circ} \mathrm{C}$ & \\
\hline
\end{tabular}

$\mathrm{F}$ refers to forward primer and $\mathrm{R}$ refers to reverse primer.

\section{Statistical analysis}

Results were expressed in the mean \pm SEM values. Differences in seminal attributes and absolute gene copy numbers between two breeds were determined by Student's $t$-test using Statistical Product and Service Solutions, Version 17.0.1 software (SPSS Inc., Chicago, IL, USA). A difference with $P<0.05$ was considered statistically significant. Copy number determination experiments by real time PCR were replicated for three times.

\section{Results}

\section{Seminal quality parameters}

The mean values of standard seminal quality parameters such as progressive forward motility, viability, membrane integrity and acrosomal integrity in the fresh semen ejaculates of Karan Fries and Sahiwal bulls have been summarized in Figure 1. No significant differences were found between semen quality parameters of Karan Fries and Sahiwal bulls like progressive motility $(76.86 \pm 0.79$ vs. $77.2 \pm 1.41)$, sperm viability $(81.24 \pm 0.92$ vs. $80.83 \pm$ 0.75 ), and acrosomal integrity (97.17 \pm 0.26 vs. $97.16 \pm$ $0.16)$. However, a significantly higher percentage of HOST-reacted spermatozoa was found in Karan Fries $(73.59 \pm 0.74)$ compared to Sahiwal $(68.62 \pm 0.71)$ bulls.

\section{Absolute copy number estimation of $S R Y, D D X 3 Y, U S P 9 Y$ and TSPY genes}

As SYBR Green binds with double stranded DNA in sequence-independent manner melting curves of reaction products were analyzed to confirm that only the specific products were amplified and circumvent any issues of non-specific fluorescence. Ten-fold dilution series of recombinant plasmid DNA for all the genes ranging from $10^{6}$ to 10 copies/ $\mu \mathrm{L}$ for $S R Y, 1.9 \times 10^{9}$ to $1.9 \times 10^{4}$ copies/ $\mu \mathrm{L}$ for $D D X 3 Y, 6 \times 10^{6}$ to $6 \times 10^{2}$ copies/ $\mu \mathrm{L}$ for $U S P 9 Y$ and from $10^{11}$ copies/ $\mu \mathrm{L}$ to $10^{7}$ copies $/ \mu \mathrm{L}$ for TSPY were prepared for generation of standard curve for quantitative analysis. The log concentration of plasmid DNA copies was plotted against the measured crossing point $(\mathrm{Cp})$ values. Linear correlations between the logarithmic number of plasmid DNA copies and $\mathrm{Cp}$ values have been presented for all genes in Figure 2.

\section{Quantification of SRY, DDX3Y, USP9Y and TSPY genes in test samples}

Absolute copy concentrations in crossbred and Indicine bulls for SRY, DDX3Y, USP9Y and TSPY genes were determined from the corresponding standard curves and transformed in $\log _{10}$ values. The mean values of absolute copy concentrations of four Y-chromosomal genes in two groups of bulls have been compared in Figure 3. The mean values of SRY and TSPY in crossbred bulls $(4.07,6.9)$ are significantly $(P<0.05)$ higher compared to Indicine bulls $(2.78,5.93)$. No significant differences were observed in the log transformed absolute copy number values of $D D X 3 Y$ and USP9Y gene between crossbred (5.8 and 5.75) and Indicine (5.72 and 5.74) bulls.

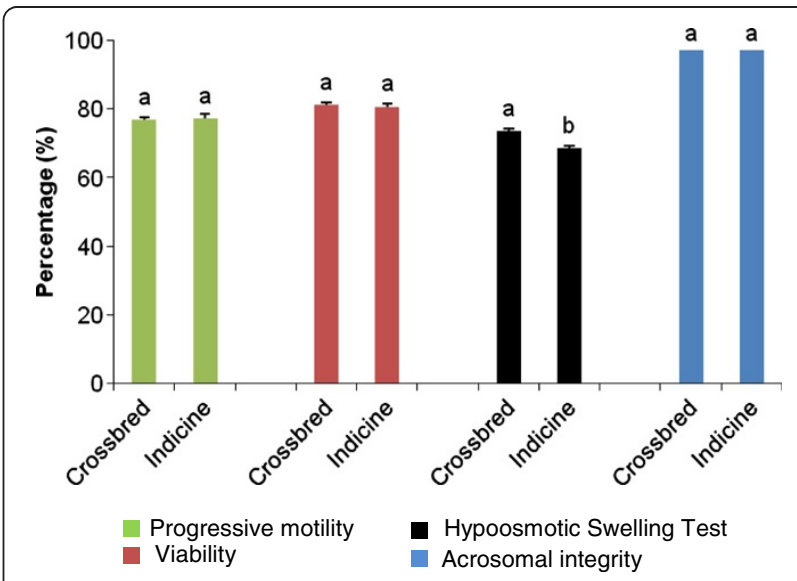

Figure 1 Seminal quality parameters of crossbred and Indicine bulls. The percentages of sperm progressive forward motility, viability, membrane integrity and acrosomal integrity were assessed in Karan Fries, a crossbred $(n=10)$ and Sahiwal, purebred Indicine $(n=10)$ bulls and the results were compared between two groups. Values are the means \pm S.E.M. of three experiments performed in two groups of bulls. Different superscripts indicate significant difference $(P<0.05)$ between two groups. 

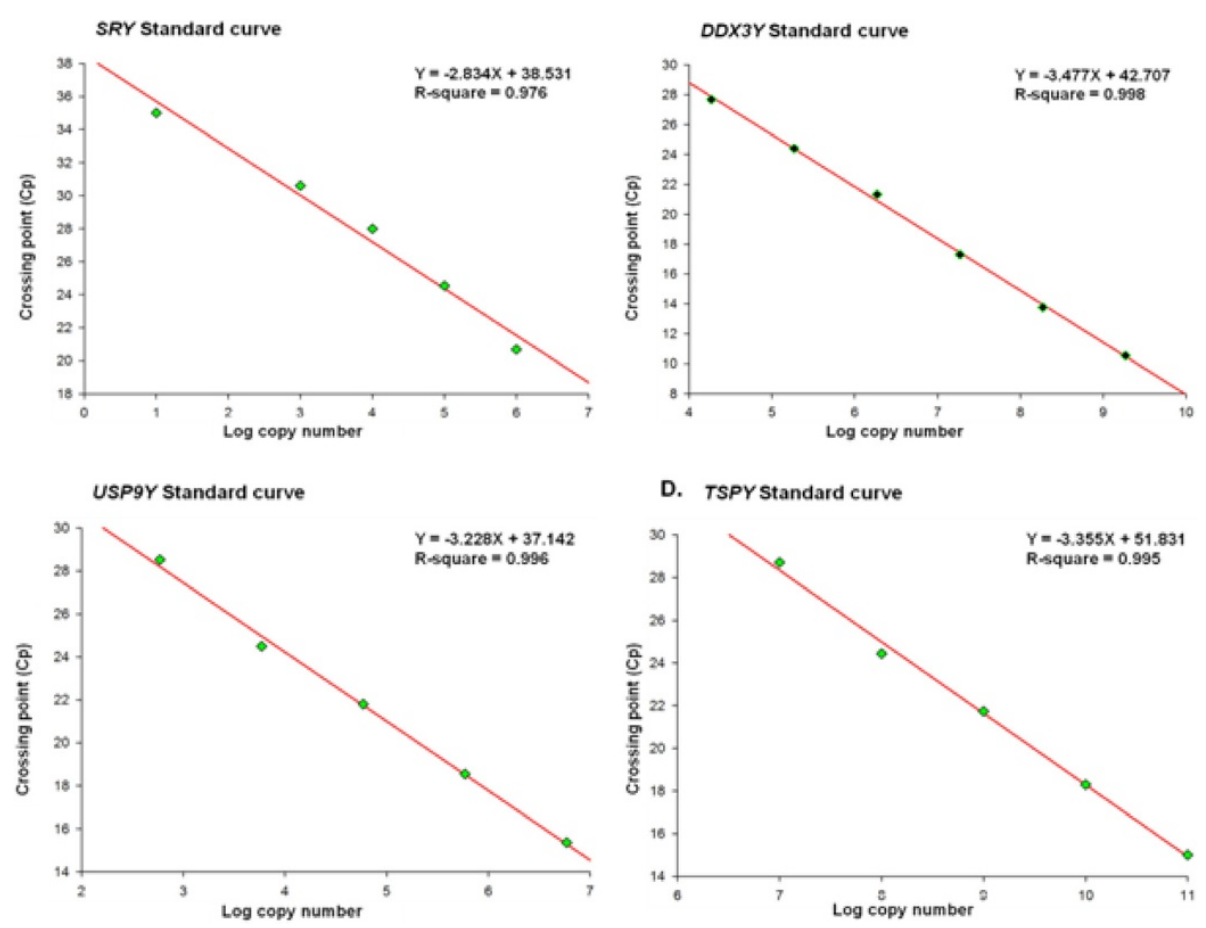

Figure 2 Construction of standard curves for SRY, DDX3Y, USP9Y and TSPY quantification. The standard curves for SRY, DDX XY, USP9Y and TSPY absolute copy number determination together with their respective line equations are shown here. Set of serial 10-fold dilutions was made for each gene. Each of these dilutions (standard dilutions) had known copies of the plasmid construct harboring the respective gene fragment as an insert. X-axis represents log transformed values of the standard copy number and Y-axis represents the crossing point (Cp) values i.e. the fractional cycle number required for the fluorescence to cross the threshold.

\section{Discussion}

The male specific region on Y chromosome (MSY) harbors genes which have crucial role in spermatogenesis, maintenance of male germ cells and fertility. Several studies have pointed out the precise correlation between compromised sperm quality and molecular abnormalities of $\mathrm{Y}$ chromosome such as copy number variation of gene-rich regions. The primary objective of the current investigation was to find out the copy number differences of Y chromosomal genes between healthy crossbred and Indicine bulls. We performed semen quality parameters to select reproductively healthy bulls and to circumvent animals having poor semen quality which could be sequelae to the detrimental changes in $\mathrm{Y}$ chromosomal gene copies. Assessment of progressive motility, plasmalemma and acrosomal integrity are the most common semen evaluation tests in cattle [25]. Analysis of semen quality attributes shows that all the bulls under study were reproductively sound. Although percentage of HOST-reacted spermatozoa was less in Sahiwal bulls $(68.62 \pm 0.71)$ compared to KF bulls (73.59 \pm 0.74 ) signifying better sperm membrane integrity in KF bulls but it does not affect the overall fertility potential of Sahiwal bulls as these bulls are regularly used for

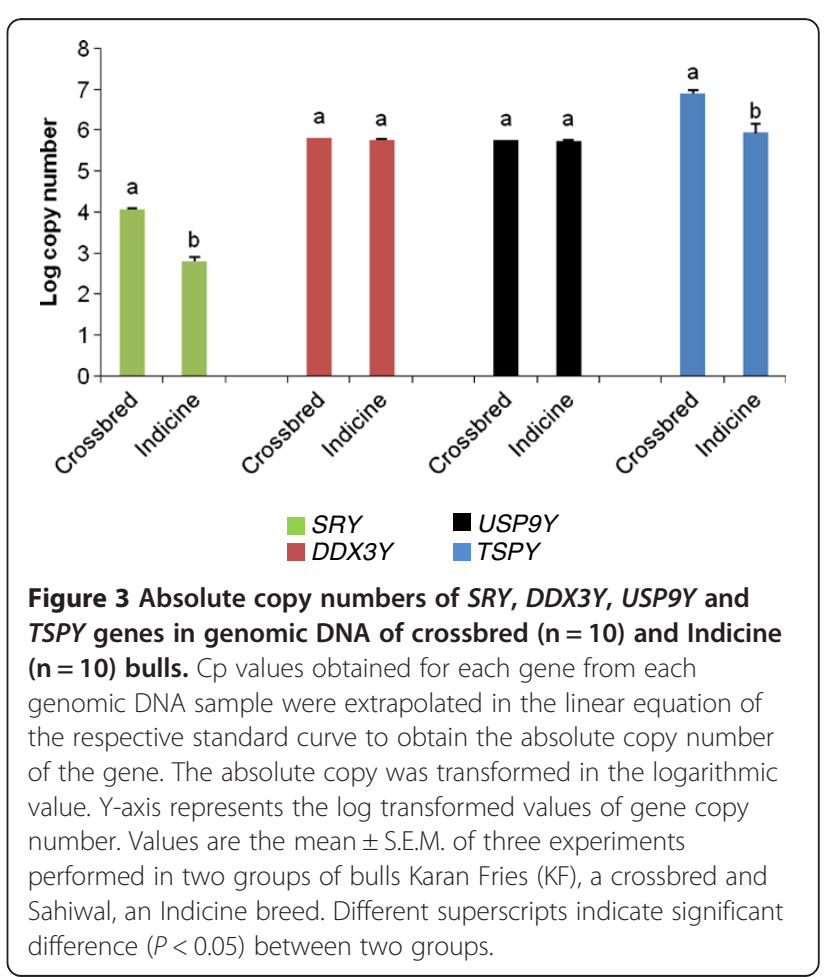


breeding program. Present study was conducted to find out whether Y chromosomal genes SRY, DDX3Y, USP9Y and TSPY copies vary in genomic DNA of crossbred and Indicine bulls. We found significantly lower number of $S R Y$ and TSPY gene copies in Indicine bulls compared with crossbred bulls. Absolute copies of DDX3Y and USP9Y gene did not vary between these two breeds. The bulls included in the present study were not paternally related. Hence, the copy numbers in different genes on Y chromosomes may be identical by state but not by descent. To our knowledge this is the first report of absolute quantitative PCR to measure levels of Y chromosomal gene copy numbers in genomic DNA samples of bovine. Compared to relative PCR methods, the use of absolute real-time PCR allows a direct comparison of the exact copy number of the genes in each genomic DNA sample [26]. The absolute quantitative PCR reported here estimates the copy numbers of the gene of interest without the requirement for a reference gene through the construction of standard curve.

Absolute copy number of $S R Y$ is significantly higher in crossbred bulls compared to Indicine bulls. $S R Y$ is a single copy gene in the genome of most mammalian species. But multiple copies of this gene have also been reported in cat, rat and rabbit and it is not clear whether multiple copies of this gene are present on cattle $\mathrm{Y}$ chromosome [27]. Copy number of TSPY gene varies substantially even between closely related mammals like human and chimpanzees [28]. In the present study log TSPY copy number varied widely from 5.48 to 6.85 in Indicine and from 6.31 to 7.13 in crossbred reflecting wide variation of this multi-copied gene within the bovine species. Studies conducted so far in human have pointed out the association of SRY, DDX3Y, USP9Y and TSPY genes with spermatogenesis and seminal quality [29-33]. However, the impact of copy number variation of these genes on reproductive parameters is still elusive. This finding is congruent with the previous report in human [31]. The phenotypic differences among different phyla or classes of organisms result from accumulation of mutations in the genome and their subsequent stabilization within the genome for the sake of adaptation to different environments [34]. So it may be assumed that normal functionality requirement of the genes in two different subspecies are different. Accordingly the genes attained that optimum level in Bos taurus and Bos indicus genome. As DDX3Y is a single copy gene in the cattle genome [27] the absolute copy number of $D D X 3 Y$ gene should not vary between two bovine subspecies. Present study also did not reveal any significant variation between crossbred and Indicine bulls in terms of absolute copy number of $D D X 3 Y$ gene. Although USP9Y is a single copy gene in most of the mammalian species the exact copy number of the gene in the cattle genome is not known [27]. No significant difference in absolute copy number of this gene between crossbreed and Indicine bulls was observed and quantity of this gene is almost equal to $D D X 3 Y$ gene copy number. So, it can be assumed that like other mammalian species cattle Y chromosome also harbors single copy of this gene.

$\mathrm{Y}$ chromosome is highly heterogeneous in both size and genetic makeup among species [28,35]. Vast structural polymorphisms have been detected in both heterochromatin and euchromatin of $\mathrm{Y}$ chromosome. Significant variations have been reported in the length of Y chromosome in different breeds of cattle [36] and Bos taurus $\times$ Bos indicus cattle [37]. The $\mathrm{Y}$ chromosome length variation observed in the present study may be due to variation in copies of TSPY array. A previous study of localization of TSPY on Bos taurus Y chromosome showed precise position of TSPY array on Yp arm [38]. Acrocentric Bos indicus $\mathrm{Y}$ has distinctly smaller p-arms than submetacentric Bos taurus Y [39]. The same study [39] proposed the phenomena of pericentric inversion with breakpoints on the proximal p-arms and on the distal band q12 of Bos indicus Y. It may be speculated that loss of TSPY gene copies occurred during the point of divergence of $Y$ chromosome in two subspecies.

\section{Conclusion}

This study suggests that the structural organization of Y chromosome varies between crossbred and Indicine bulls which are reproductively healthy as observed from assessment of semen attributes. Absolute copy number of $D D X 3 Y$ and $U S P 9 Y$ do not vary between these two bovine subspecies probably because of their single-copy presence in the genome. TSPY, a multicopy gene in bovine genome, varies substantially between crossbred and Indicine bulls. Variation in Y chromosome length between crossbred and Indicine bulls might be due to the copy number variation of TSPY array and SRY gene. These findings establish a foundation for association study between chromosomal genes copy number and reproductive fitness in crossbred and Indicine bulls and existence of any correlation between them will be valuable in determining breeding programs.

\section{Competing interests \\ None of the authors have any competing interest to declare.}

\section{Authors' contributions}

All listed authors have made substantial contributions to: the research design, analysis or interpretation of data and in drafting the paper. All authors read and approved the final manuscript.

\section{Acknowledgement}

This study was supported by World Bank funded National Agricultural Innovation Project (C4/C30015). The authors also thank Dr. A.K. Chakravarty, Principal Scientist, Animal Genetics and Breeding Division, for providing assistance in collecting blood and semen samples. 


\section{Author details}

${ }^{1}$ Animal Genomics Lab, Animal Biotechnology Centre, National Dairy Research Institute, Karnal, India. ${ }^{2}$ Department of Veterinary Biochemistry, College of Veterinary Sciences \& Animal Husbandry, Central Agricultural University, Selesih, Aizawl, Mizoram, India.

Received: 13 December 2012 Accepted: 25 March 2013

Published: 4 April 2013

\section{References}

1. Lahn BT, Page DC: Functional coherence of the human Y-chromosome. Science 1997, 278:675-680.

2. Pecon Slattery J, Sanner-Wachter L, O'Brien SJ: Novel gene conversion between $X-Y$ homologues located in the nonrecombining region of the Y chromosome in Felidae (Mammalia). Proc Natl Acad Sci USA 2000, 97:5307-5312

3. Skaletsky H, Kuroda-Kawaguchi T, Minx PJ, et al: The male-specific region of the human $\mathrm{Y} \mathrm{Chr}$ is a mosaic of discrete sequence classes. Nature 2003, 423(6942):825-837.

4. Lin YW, Thi DA, Kuo PL, Hsu CC, Huang BD, Yu YH, Vogt PH, Krause W, Ferlin A, Foresta C, Bienvenu T, Schempp W, Yen PH: Polymorphisms associated with the DAZ genes on the human Y chromosome. Genomics 2005, 86:431-438

5. Beckmann JS, Estivill X, Antonarakis SE: Copy number variants and genetic traits: Closer to the resolution of phenotypic to genotypic variability. Nat Rev Genet 2007, 8:639-646.

6. Conrad B, Antonarakis SE: Gene duplication: A drive for phenotypic diversity and cause of human disease. Annu Rev Genomics Hum Genet 2007, 8:17-35.

7. Feuk L, Carson AR, Scherer SW: Structural variation in the human genome. Nat Rev Genet 2006, 7:85-97.

8. McCarroll SA, Altshuler DM: Copy-number variation and association studies of human disease. Nat Genet 2007, 39:S37-S42.

9. Waters PD, Wallis MC, Marshall Graves JA: Mammalian sex-Origin and evolution of the Y chromosome and SRY. Semin Cell Dev Biol 2007, 18:389-400

10. Sun C, Skaletsky H, Birren B, Devon K, Tang Z, Silber S, Oates R, Page DC: An azoospermic man with a de novo point mutation in the Y-chromosomal gene USP9Y. Nat Genet 1999, 23:429-432.

11. Krausz C, Degl'Innocenti S, Nuti F, Morelli A, Felici F, Sansone M, Varriale G, Forti G: Natural transmission of USP9Y gene mutations: a new perspective on the role of AZFa genes in male fertility. Hum Mol Genet 2006, 15:2673-2681

12. Luddi A, Margollicci M, Gambera L, Serafini F, Cioni M, De Leo V, Balestri P, Piomboni P: Spermatogenesis in a man with complete deletion of USP9Y. N Engl J Med 2009, 60:881-885.

13. Lau YF-C, Li Y, Kido T: Role of the Y-located putative gonadoblastoma gene in human spermatogenesis. Syst Biol Reprod Med 2011, 57(1-2):27-34.

14. Kieffer NM, Cartwright TC: Sex Chromosome polymorphism in domestic cattle. J Hered 1968, 59:35-37.

15. Pinheiro LEL, Moraes JCF, Mattevi MS, Erdtmann B, Salzano FM, Mies Filho A: Two types of $Y$ chromosome in a Brazilian cattle breed. Caryologia 1980, 33:25-32.

16. Salisbury GW, Van den Mark NL, Lodge JR: Physiology of Reproduction and Artificial Insemination of Cattle. Delhi: CBS Publishers and Distributors; 1985.

17. Tomar NS: Artificial Insemination and Reproduction of Cattle and Buffaloes. Allahabad: Saroj Prakashan; 1997.

18. Selvaraju S, Ravindra JP, Ghosh J, Gupta PSP, Suresh KP: Evaluation of sperm functional attributes in relation to in vitro sperm-zona pellucida binding ability and cleavage rate in assessing frozen thawed buffalo (Bubalus bubalis) semen quality. Anim Reprod Sci 2008, 106:311-321.

19. Revell SG, Mrode RA: An osmotic resistance test for bovine semen. Anim Reprod Sci 1994, 36:77-86.

20. Cross NL, Morales P, Overstreet JW, Hanson FW: Two simple methods for detecting acrosome-reacted human sperm. Gamete Res 1986, 15:213-226.

21. Perry RL, Naeeni M, Barratt CL, Warren MA, Cooke ID: A time course study of capacitation and the acrosome reaction in human spermatozoa using revised chlortetracycline pattern classification. Fertil Steril 1995, 64:150-159.

22. Sambrook J, Russell D: Molecular cloning: A laboratory manual. New York: Cold Spring Harbor Press; 2001
23. Whelan JA, Russel NB, Whelan MA: A method for the absolute quantification of cDNA using real time PCR. J Immunol Methods 2003, 278:261-269.

24. Rasmussen R: Quantification on the LightCycler. In Rapid cycle real-time PCR: methods and applications. Edited by Meuer S, Wittwer C, Nakagawara K. New York: Springer; 2001:21-34.

25. Rodriguez-Martinez $\mathrm{H}$ : Laboratory semen assessment and prediction of fertility: still utopia? Reproduction in Domestic Animal 2003, 38:312-318.

26. Scheurer ME, Dillon LM, Chen Z, Follen M, Adler-Storthz K: Absolute quantitative real-time polymerase chain reaction for the measurement of human papillomavirus E7 mRNA in cervical cytobrush specimens. Infect Agent Cancer 2007, 2:8.

27. Paria N, Raudsepp T, Pearks Wilkerson AJ, O'Brien PCM, Ferguson-Smith MA, Love CC, Arnold C, Rakestraw P, Murphy WJ, Chowdhary BP: A gene catalogue of the euchromatic male-pecific region of the horse $Y$ chromosome: Comparison with human and other mammals. PLOS One 2011, 6(7):e21374.

28. Hughes JF, Skaletsky H, Pyntikova T, Graves TA, van Daalen SK, Minx PJ Fulton RS, McGrath SD, Locke DP. Friedman C, Trask BJ, Mardis ER, Warren WC, Repping S, Rozen S, Wilson RK, Page DC: Chimpanzee and human Y chromosomes are remarkably divergent in structure and gene content. Nature 2010, 463:536-539.

29. Giachini C, Nuti F, Turner DJ, Laface I, Xue Y, Daguin F, et al: TSPY1 copy number variation influences spermatogenesis and shows differences among Y lineages. J Clin Endocrinol Metab 2009, 94:4016-4022.

30. Lardone MC, Parodi DA, Valdevenito R, Ebensperger M, Piottante A, Madariaga M, Smith R, Pommer R, Zambrano N, Castro A: Quantification of DDX3Y, RBMY1, DAZ and TSPY mRNAs in testes of patients with severe impairment of spermatogenesis. Mol Hum Reprod 2007, 13(10):705-712.

31. Vodicka R, Vrtel R, Dusek L, Singh AR, Krizova K, Svacinova V, Horinova V, Dostal J, Oborna I, Brezinova J, Sobek A, Santavy J: TSPY gene copy number as a potential new risk factor for male infertility. Reprod Biomed Online $2007,14: 579-587$.

32. Vijayakumar S, Hall DC, Reveles XT, Troyer DA, Thompson IM, Garcia D, Xiang R, Leach RJ, Johnson-Pais TL, Naylor SL: Detection of recurrent copy number loss at Yp11.2 involving TSPY gene cluster in prostate cancer using array-based comparative genomic hybridization. Cancer Res 2006, 66:4055-4064

33. Modi D, Shah C, Sachdeva G, Gadka S, Bhartiya D, Puri C: Ontogeny and cellular location of SRY transcripts in the human testes and its detection in spermatozoa. Reproduction 2005, 130(5):603-613.

34. Nei M: The new mutation theory of phenotypic evolution. Proc Natl Acad Sci USA 2007, 104:12235-12242.

35. Liu W: Comparative genomics of the Y chromosome and male fertility. In Reproductive genomics in domestic animals. Edited by Jiang Z, Ott TL. lowa: Wiley-Blackwell; 2010:129-156.

36. De Giovanni A, Cribiu EP: Etude des variations du chromosome $Y$ dans quatre races bovines italiennes. III - Colloque de Cytogénétique des animaux domestiques. Ann Genet Sel Anim 1977, 9:527-527.

37. Mandal A, Sharma A: Variations in the length of the $Y$ chromosome and the seminal attributes of Karan Fries bulls. Vet Res Commun 2003, 27(7): 567-575.

38. Hamilton CK, Favetta LA, Di Meo GP, Floriot S, Perucatti A, Peippo J, Kantanen J, Eggen A, lannuzzi L, King WA: Copy Number Variation of Testis-Specific Protein, Y-Encoded (TSPY) in 14 Different Breeds of Cattle (Bos taurus). Sex Dev 2009, 3:205-213

39. De Meo GP, Perucatti A, Floriot $S$, Incarnato D, Rullo R, Caputi Jambrenghi A Ferretti L, Vonghia G, Cribiu E, Eggen A, lannuzzi L: Chromosome evolution and improved cytogenetic maps of the $Y$ chromosome in cattle, zebu, river buffalo, sheep and goat. Chromosome Res 2005, 13:349-355.

doi:10.1186/2049-1891-4-15

Cite this article as: Mukherjee et al: Absolute copy number differences of $Y$ chromosomal genes between crossbred (Bos taurus $\times$ Bos indicus) and Indicine bulls. Journal of Animal Science and Biotechnology 2013 4:15. 